NBER WORKING PAPER SERIES

\title{
RETURN OF THE SOLOW PARADOX? IT, PRODUCTIVITY, AND EMPLOYMENT IN U.S. MANUFACTURING
}

\author{
Daron Acemoglu \\ David Autor \\ David Dorn \\ Gordon H. Hanson \\ Brendan Price \\ Working Paper 19837 \\ http://www.nber.org/papers/w19837 \\ NATIONAL BUREAU OF ECONOMIC RESEARCH \\ 1050 Massachusetts Avenue \\ Cambridge, MA 02138 \\ January 2014
}

We thank Eli Berman, Susan Houseman, Stephen Machin, Kenneth Troske, and seminar participants at the 2014 AEA session "Inequality in the Future" for valuable comments and assistance with data. Acemoglu and Autor acknowledge financial support from the Sloan Foundation (Grant 2011- 10-12). Autor and Hanson acknowledge funding from the National Science Foundation (Grant SES-1227334). Dorn acknowledges funding from the Spanish Ministry of Science and Innovation (ECO2010-16726 and JCI2011-09709). Price acknowledges financial support from the Hewlett Foundation. The views expressed herein are those of the authors and do not necessarily reflect the views of the National Bureau of Economic Research.

NBER working papers are circulated for discussion and comment purposes. They have not been peerreviewed or been subject to the review by the NBER Board of Directors that accompanies official NBER publications.

(C) 2014 by Daron Acemoglu, David Autor, David Dorn, Gordon H. Hanson, and Brendan Price. All rights reserved. Short sections of text, not to exceed two paragraphs, may be quoted without explicit permission provided that full credit, including $\odot$ notice, is given to the source. 
Return of the Solow Paradox? IT, Productivity, and Employment in U.S. Manufacturing Daron Acemoglu, David Autor, David Dorn, Gordon H. Hanson, and Brendan Price NBER Working Paper No. 19837

January 2014

JEL No. J2,L60,O3

\begin{abstract}
An increasingly influential "technological-discontinuity" paradigm suggests that IT-induced technological changes are rapidly raising productivity while making workers redundant. This paper explores the evidence for this view among the IT-using U.S. manufacturing industries. There is some limited support for more rapid productivity growth in IT-intensive industries depending on the exact measures, though not since the late 1990s. Most challenging to this paradigm, and our expectations, is that output contracts in IT-intensive industries relative to the rest of manufacturing. Productivity increases, when detectable, result from the even faster declines in employment.
\end{abstract}

Daron Acemoglu

Department of Economics, E18-269D

MIT

77 Massachusetts Avenue

Cambridge, MA 02139

and CIFAR

and also NBER

daron@mit.edu

David Autor

Department of Economics, E17-216

MIT

77 Massachusetts Avenue

Cambridge, MA 02139

and NBER

dautor@mit.edu

David Dorn

CEMFI

Casado del Alisal 5

28014 Madrid

Spain

dorn@cemfi.es
Gordon H. Hanson

IR/PS 0519

University of California, San Diego

9500 Gilman Drive

La Jolla, CA 92093-0519

and NBER

gohanson@ucsd.edu

Brendan Price

MIT Economics

50 Memorial Drive

Cambridge, MA 02142

bmprice@mit.edu 
An increasingly popular "technological-discontinuity" paradigm, powerfully articulated in Brynjolfsson and McAfee (2011), argues that U.S. workplaces have been, and will continue to be, automated and transformed by information technology (IT) capital. Two implications of this transformation are emphasized. First, all sectors - but particularly IT-intensive sectors - are experiencing major increases in productivity. Thus, Solow's paradox is long since resolved: computers are now everywhere in our productivity statistics. ${ }^{1}$ Second, IT-powered machines will increasingly replace workers, ultimately leading to a substantially smaller role for labor in the workplace of the future.

Adding urgency to this argument, labor's share of national income has fallen in numerous developed and developing countries over roughly the last three decades, a phenomenon that Karabarbounis and Neiman (forthcoming) attribute to IT-enabled declines in the relative prices of investment goods. And many scholars have pointed to the seeming "decoupling" between robust U.S. productivity growth and sclerotic or negligible growth rates of median U.S. worker compensation (Fleck, Glaser and Sprague 2011) as evidence that the "race against the machine" has already been run — and that workers have lost.

This paper provides a simple evaluation of this viewpoint using detailed data from the U.S. manufacturing sector. We find, unexpectedly, that earlier "resolutions" of the Solow paradox may have neglected certain paradoxical features of IT-associated productivity increases, at least in U.S. manufacturing. First, focusing on IT-using (rather than IT-producing) industries, the evidence for faster productivity growth in more IT-intensive industries is somewhat mixed and depends on the measure of IT intensity used. There is also little evidence of faster productivity growth in ITintensive industries after the late 1990s. Second and more importantly, to the extent that there is more rapid growth of labor productivity $(\ln (Y / L))$ in IT-intensive industries, this is associated with declining output $(\ln Y)$ and even more rapidly declining employment $(\ln L)$. If IT is indeed increasing productivity and reducing costs, at the very least it should also increase output in ITintensive industries. As this does not appear to be the case, the current resolution of the Solow paradox does not appear to be what adherents of the technological-discontinuity view had in mind.

\section{Information Technology and Labor Productivity}

We employ the NBER-CES Manufacturing Industry Database, sourced from the Annual Survey of Manufacturers (Becker, Gray and Marvakov 2013), to estimate and plot a set of simple, descriptive regressions that chart the relationship between IT investment and industry-level outcomes for the time period 1980 through $2009 .^{2}$ Our regression model takes the form

\footnotetext{
${ }^{1}$ Robert Solow's comment on computers appears in his 1987 New York Times Book Review article: “...what everyone feels to have been a technological revolution, a drastic change in our productive lives, has been accompanied everywhere, including Japan, by a slowing-down of productivity growth, not by a step up. You can see the computer age everywhere but in the productivity statistics."

${ }^{2}$ The attached appendix provides a detailed description of our data construction, along with several supplemental analyses.
} 


$$
\log Y_{j t}=\gamma_{\mathbf{j}}+\delta_{\mathbf{t}}+\sum_{t=81}^{09} \beta_{t} \times I T_{j}+e_{j t},
$$

where $Y$ is an outcome variable (expressed in log points), $\gamma$ is a vector of industry fixed effects, $\delta$ is a vector of time dummies, IT is a static measure of industry IT-intensity, and $e$ is an error term. This specification normalizes the coefficient on the IT variable to zero in the base year, and hence the series $\left\{\beta_{81}, \beta_{82}, \ldots, \beta_{09}\right\}$ may be read as the level of the coefficient on IT in each subsequent year relative to 1980. Following Berman, Bound and Griliches (1994) and Autor, Katz and Krueger (1998), we measure IT intensity as the ratio of industry computer (IT) expenditures to total capital expenditures. $^{3}$

Figure 1A, which plots the over-time relationship between IT-intensity and the log of real shipments per worker (our preferred productivity measure), ${ }^{4}$ shows a dramatic differential rise in output per worker in IT-intensive industries throughout the entire 1980 through 2009 period. But crucially, this pattern is almost entirely driven by the computer-producing sector (NAICS 334). ${ }^{5}$ Across the entire manufacturing sector, industries that had a one standard deviation higher rate of IT investment over the sample period saw differential productivity gains averaging a remarkable 10 log points per decade between 1980 and 2009. Excluding computer-producing industries, however, results in a murkier picture. There is some differential productivity growth in IT-intensive industries in the late 1990s, but this effect is very small (on the order of a few percentage points at its peak) and subsides after 2001. By 2009, there is no net relative productivity gain in IT-intensive industries over the full sample period.

This productivity growth pattern is unexpected in light of the earlier resolution of the Solow Paradox (e.g., Oliner and Sichel, 2000). One possible explanation is that our focus on manufacturing is misplaced-perhaps the productivity gains from IT investments are taking place elsewhere. While our data do not allow us to exclude this possibility, earlier evidence from Stiroh (2002) suggests that the IT-driven productivity growth in the 1990s was not specific to non-manufacturing and may in fact have been more pronounced in manufacturing. Moreover, productivity growth in U.S. manufacturing has generally exceeded that outside of manufacturing for many decades, and this productivity growth differential rose sharply during the 1990s (Fleck, Glaser and Sprague 2011). ${ }^{6}$

\footnotetext{
${ }^{3}$ Specifically, we compute this ratio in 1977, 1982, 1987, 1992, 2002 and 2007 (no 1997 measure is available), take the average across these six data points (placing slightly greater weight on the last two periods to compensate for the absence of the 1997 measure), and standardize the result so that the final measure has zero mean and unit standard deviation across employment-weighted industries.

${ }^{4}$ We choose this productivity construct because it is unaffected by the choice of deflators for intermediate inputs: if the productivity of a dollar of IT investment rises over time due to IT quality improvements, this should raise shipments in IT-using industries. By contrast, the effect of rising IT quality on value-added and TFP in IT-using industries is ambiguous. Nevertheless, results using value added measures are very similar (see Figure A6 of the appendix).

${ }^{5}$ Our focus on NAICS 334 follows Houseman, Bartik and Sturgeon (2013), who underscore that the relatively robust growth of productivity and value-added in U.S. manufacturing over the last two decades is substantially driven by IT-producing industries. What Figure 1A contributes to this discussion is the finding that outside of the IT-producing industries, there is little relationship between IT investments and productivity growth.

${ }^{6}$ Table 2 of Stiroh (2002) shows somewhat slower differential productivity growth of IT-intensive industries relative to 1987-1995 when durable goods manufacturing is excluded from the sample (compare columns 4 and 5 in the upper
} 

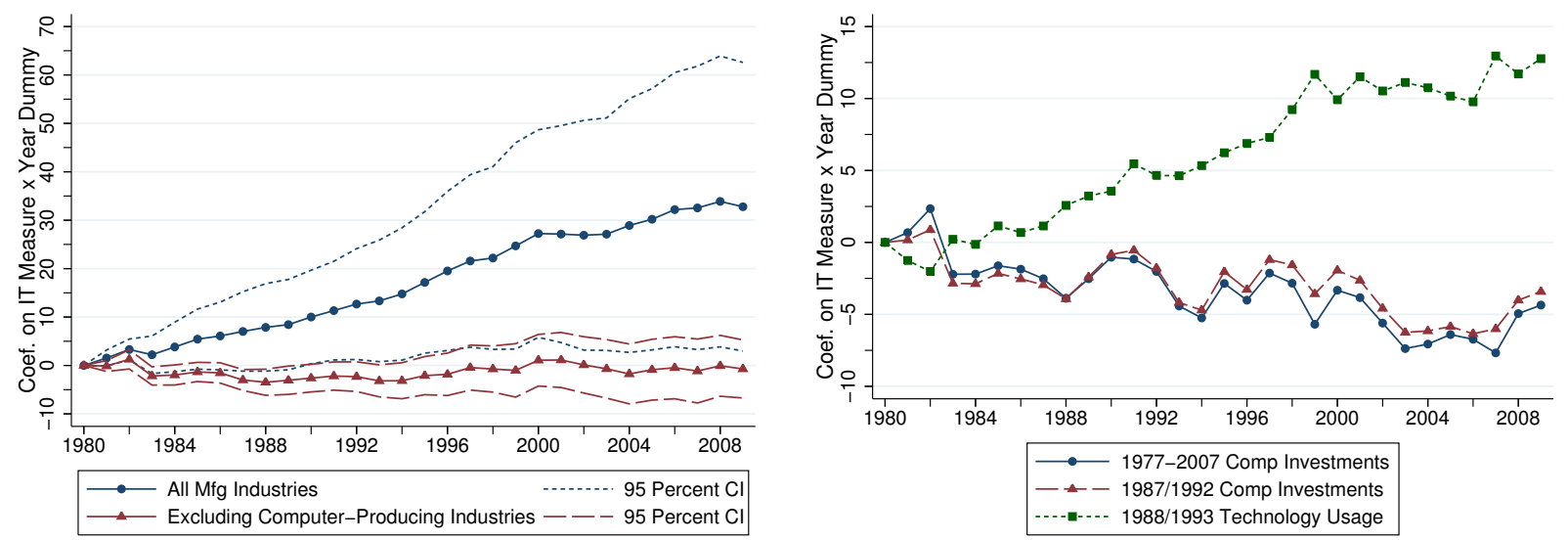

Figure 1: IT Intensity and Log Real Shipments per Worker, 1980-2009

Panel A: $\mathrm{n}=387$ manufacturing industries ( $\mathrm{n}=359$ when excluding computer-producing industries). IT intensity is defined as the ratio of computer investments to total investments, averaged over 19772007. Panel B: $n=120$ non-computer-producing industries comprising SIC 34-38. The two Computer Investment series in Panel B define IT intensity as in Panel A, using data from the indicated years. The Technology Usage series defines IT intensity as the employment-weighted share of 17 advanced technologies used by plants within the industry. IT measures are normalized to have zero mean and unit standard deviation. Regressions are employment weighted and include industry and year fixed effects. Confidence intervals are based on standard errors clustered by industry.

A second category of explanation for these unexpected results is that our measure of IT investment, constructed by averaging computer investment data from 1977 through 2007, misses the mark. Plausibly, an IT investment measure that focused on the most recent years of IT investments - rather than averaging over three decades - might prove more predictive of recent industry-level productivity growth since such a measure would better reflect the current locus of the IT frontier. We explore this possibility in Figure A1 of the appendix by plotting the over-time relationship between labor productivity and IT investment in non-computer-producing industries using three different vintages of IT investment measures, corresponding to averages of 1977 and 1982, 1987 and 1992, and 2002 and 2007 investments, as well as our preferred measure from panel A, which is simply the weighted average of all six years of investment data. This analysis does not lend support to the hypothesis that our primary IT measure is "out of date." Indeed, the strongest predictor of industry relative productivity growth during the 1990s is the 1977/1982 investment measure, whereas the most recent measure (from 2002/2007) is the weakest predictor. Moreover, none of these measures predicts relative productivity growth in IT-intensive industries during the 2000s.

A further concern with our simple IT investment measure is that it may fail to capture recent innovations in IT that are embodied in newer manufacturing technologies, such as computer numerically controlled machinery, pick and place robots, automated guided vehicle systems, material working lasers, etc. To explore this possibility, we exploit data from the Census Bureau's Survey of Manufacturing Technology (SMT) conducted in 1988 and 1993, and previously used by Doms, Dunne

panel), though the pattern is reversed when the comparison is to 1977-1995 in the second panel. 
and Troske (1997), which surveyed plants about their use of seventeen advanced manufacturing technologies. Specifically, we reestimate equation (1) while replacing the computer investment measure with a SMT-based measure of the employment-weighted mean fraction of the seventeen technologies in use across plants in the 120 4-digit industries for which they are available (averaging over 1988 and 1993). We exclude computer-producing industries from this analysis (and all subsequent analyses), since our focus is on induced productivity gains in IT-using industries. Figure 1B, which plots these estimates, documents that labor productivity rose relatively rapidly in SMT-intensive manufacturing industries during the 1980s and 1990s. As with the computer investment measure, however, the relationship between SMT technology adoption and industry-level labor productivity plateaus in the late 1990s, and shows little further relative gain in labor productivity after 1999.

The SMT survey was only administered to plants in five major high-tech sectors (SICs 3438) - presumably those sectors where the seventeen manufacturing technologies studied were most applicable. ${ }^{7}$ To check whether our main results for computer investment carry over to this restricted set of sectors, we reestimate our prior (Figure 1A) model using only these five high-tech sectors (excluding computer-producing industries), applying two vintages of the computer investment measure: our main measure using data from 1977 through 2007; and a measure that uses only investment data from 1987 and 1992, chosen to parallel the SMT's survey years of 1988 and 1993. These estimates, also plotted in Figure 1B, indicate that the computer investment measure is a weaker predictor of productivity growth in these five high-tech sectors than is the SMT-based measure. However, neither the SMT nor the computer investment measure predicts a differential rise in productivity in IT-intensive industries after the late 1990s.

In sum, our evidence so far suggests very limited IT-driven productivity growth in computerintensive manufacturing industries, with the contrasting result of more rapid productivity growth in industries using advanced manufacturing technologies more intensively. Different measures of IT intensity thus appear to give different results. Our result based on advanced technologies may suggest that adoption of high-tech, IT-related capital has contributed to rapid productivity growth in manufacturing, but our subsequent results cast doubt on this interpretation.

\section{What Drives Rising $\mathrm{Y} / \mathrm{L}$ - The Numerator or the Denominator?}

Since our measure of labor productivity equals the log ratio of gross output to payroll employment, the positive relationship we detect in Figure 1 between industry IT and output per worker during the 1990s implies that industry output is rising proportionately faster than employment in IT-intensive industries. But it does not reveal whether either output is rising faster or employment is falling faster relative to non-IT-intensive industries.

We thus explore these two outcomes (output and employment) separately in the remaining figures. Under the assumption that IT-intensive industries are seeing improvements in technology and automation and reductions in production costs, we would expect them to experience a relative

\footnotetext{
${ }^{7}$ These SICs are fabricated metal products, non-electrical machinery, electrical and electronic equipment, transportation equipment, and instruments and related products industries.
} 

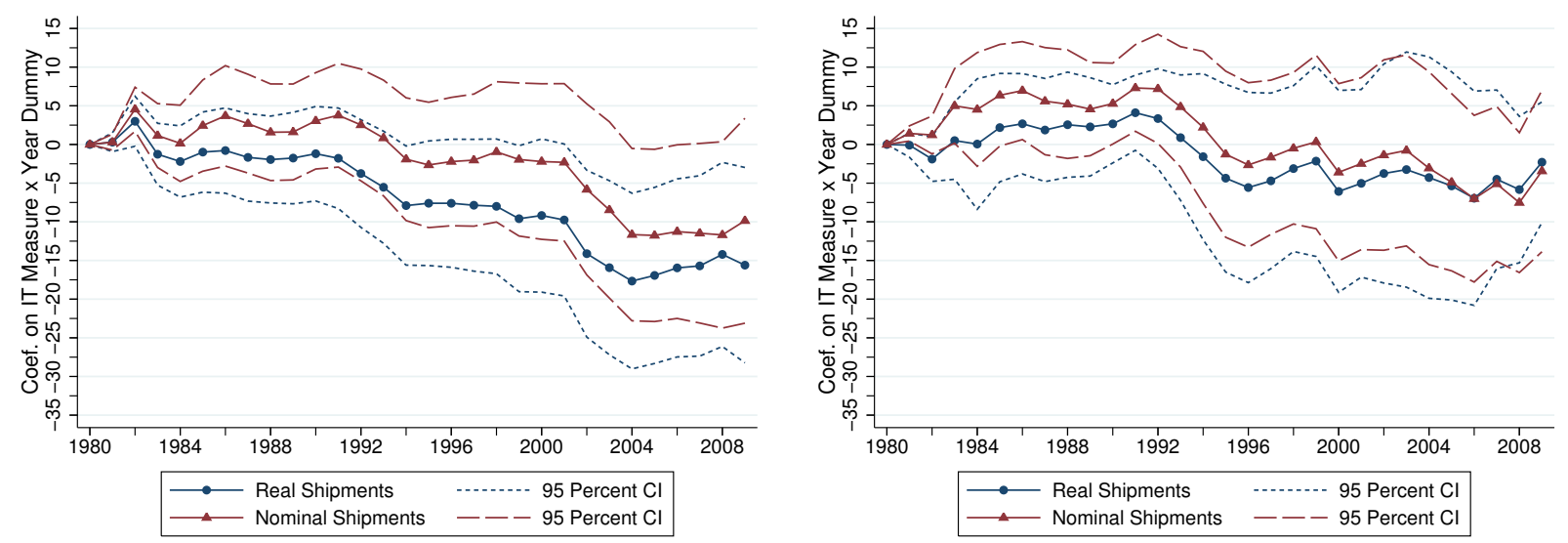

Figure 2: IT Intensity and Log Real and Nominal Shipments, 1980-2009

Panel A: $\mathrm{n}=359$ non-computer-producing manufacturing industries, and IT intensity is based on 1977-2007 computer investments. Panel B: $\mathrm{n}=120$ non-computer-producing industries in SIC 3438, and IT intensity is based on 1988/1993 technology usage. Real shipments are computed using industry-specific price deflators.

expansion in output. The implications for employment are of course ambiguous - and this could make the labor productivity measure somewhat more difficult to interpret - because these industries may be shedding labor as they automate, but may also increase employment as they expand.

Figure 2A examines the numerator of this ratio, the logarithm of shipments, measured either as real or nominal shipments, using our 1977-2007 measure of computer investments. The relationship between IT-intensity and industry shipments is almost precisely the opposite of expectations: both real and nominal shipments rise at best modestly in IT-intensive industries (relative to nonIT-intensive industries) during the 1980s and then commence a relative decline in the 1990s that accelerates in the 2000s. Thus, relative output growth in IT-intensive industries begins to fall exactly when the IT-productivity payoff is thought to have materialized. While it could be that demand for the output of IT-intensive industries is price inelastic, this would not explain why real shipments decline. If, on the other hand, IT-intensive industries have upgraded their quality relative to other industries and this is not fully captured by the industry price deflators, this mismeasurement could explain the decline in real shipments but not the decline in nominal shipments. The two sets of results together defy a simple explanation.

We repeat this exercise in Figure 2B using the embodied IT capital measures from the SMT database. Though we detected above a more robustly positive relationship between use of advanced manufacturing technologies and growth in output per worker, Figure 2B makes clear that this pattern is not driven by rising relative output in SMT-intensive industries. Instead, real (and nominal) shipments in industries that heavily adopted these technologies also exhibit a sharp relative decline between 1992 and 1996, with no rebound thereafter.

The combination of rising log output per worker and falling log output in IT-intensive industries implies that log employment must have fallen even more rapidly than output in these industries, 

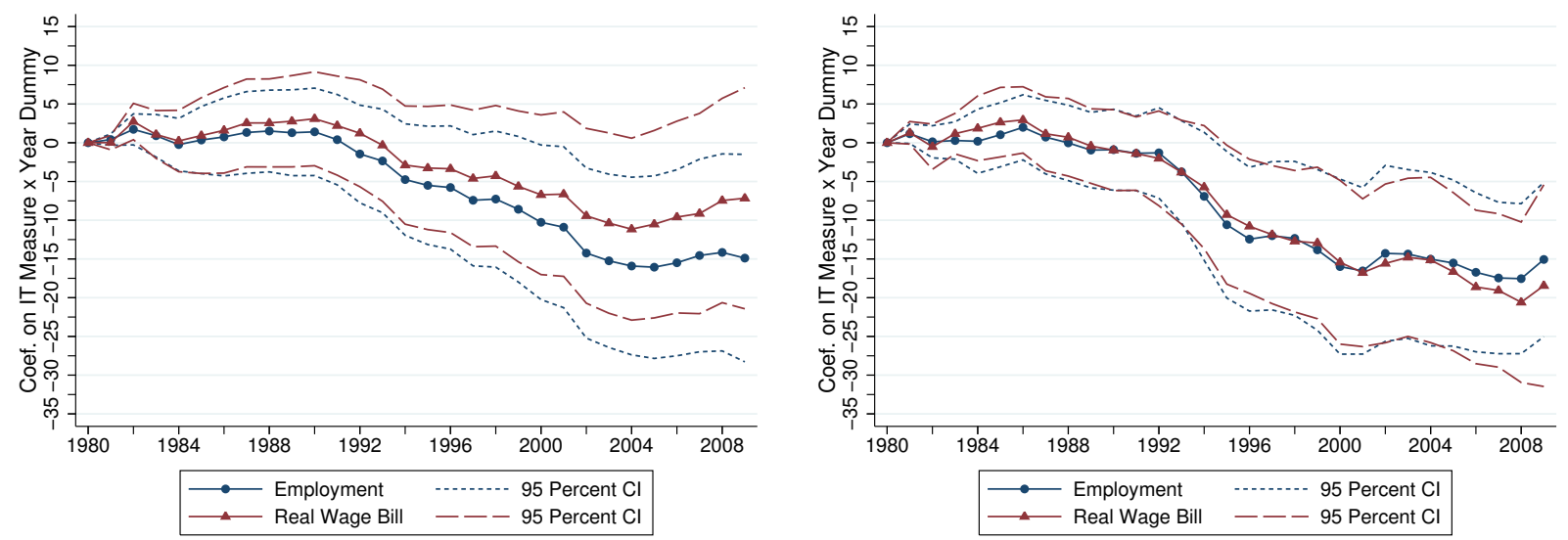

Figure 3: IT Intensity and Log Employment and Real Wage Bill, 1980-2009

Panel A: $\mathrm{n}=359$ non-computer-producing manufacturing industries, and IT intensity is based on 1977-2007 computer investments. Panel B: $n=120$ non-computer-producing industries in SIC 34-38, and IT intensity is based on 1988/1993 technology usage.

a reality confirmed by Figure 3. Whether measured by total employment or by the real wage bill, labor input in technology intensive industries declined sharply from the early 1990s through the early 2000s (in relative terms), and then roughly held steady during the 2000s. Thus, the flattening relationship between IT investments - measured either as computer investments (panel A) or usage of advanced manufacturing technologies (panel B) - and labor productivity in the 2000s is proximately explained by the cessation of relative employment declines in these industries. Though one can read this evidence as corroborating the "worker-less workplace" narrative of recent technological change, the timing appears wrong: relative employment declines in technology-intensive industries halted or modestly reversed from 2000 forward, which is inconsistent with the premise that IT has contributed to the slackening of labor demand in the new millennium.

\section{Conclusion}

This paper documents a pattern of growth among IT-using manufacturing industries that stands in contrast to the powerful and intuitively appealing view that IT is making workers redundant through outsized productivity gains. While we find some evidence of differential productivity growth in ITintensive manufacturing industries, this depends on the measure of IT intensity and is never visible after the late 1990s. More importantly, when present, it is driven by declining relative output accompanied by even more rapid declines in employment. It is difficult to square these output declines with the notion that computerization and IT embodied in new equipment are driving a productivity revolution, at least in U.S. manufacturing. It may well be that IT-induced technological changes are transforming non-manufacturing, or that they are so widespread as to be taking place rapidly even in non-IT-intensive industries. But at the very least, our evidence suggests that the previouslyproposed resolutions of the Solow Paradox need to be critically examined, and that proponents of 
the technological-discontinuity view need to provide more direct evidence of the IT-induced transformation in the U.S. economy. Prior declarations of the death of the Solow Paradox may have been premature.

\section{References}

Acemoglu, Daron, David Autor, David Dorn, Gordon Hanson, and Brendan Price. 2013. "Import Competition and the Great US Employment Sag of the 2000s." Mimeo.

Autor, David, David Dorn, and Gordon Hanson. 2013. "The China Syndrome: Local Labor Market Effects of Import Competition in the United States." American Economic Review, 103(6), 2121-2168.

Autor, David H., Lawrence F. Katz and Alan B. Krueger, 1998. "Computing Inequality: Have Computers Changed the Labor Market?" Quarterly Journal of Economics, 113 (4), November, 11691214.

Becker, Randy, Wayne Gray, and Jordan Marvakov. 2013. "NBER-CES Manufacturing Industry Database." National Bureau of Economic Research. http://www.nber.org/nberces (accessed March 23, 2013).

Berman, Eli, John Bound, and Zvi Griliches. 1994. "Changes in the Demand for Skilled Labor Within U.S. Manufacturing Industries: Evidence from the Annual Survey of Manufacturing." Quarterly Journal of Economics, 109(2), 367-397.

Brynjolfsson, Erik and Andrew McAfee. 2011. Race Against the Machine. Lexington, MA: Digital Frontier Press.

Doms, Mark, Timothy Dunne, and Kenneth R. Troske. 1997. Workers, Wages, and Technology. Quarterly Journal of Economics, 112(1), 253-290.

Fleck, Susan, John Glaser, and Shawn Sprague. 2011. "The Compensation-Productivity Gap: A Visual Essay." Monthly Labor Review, January, 57-69.

Houseman, Susan N., Timothy Bartik, and Timothy Sturgeon. 2013. "Measuring Manufacturing: Problems of Interpretation and Biases in the U.S. Statistics." Mimeo, Upjohn Institute.

Karabarbounis, Loukas and Brent Neiman. Forthcoming. "The Global Decline of the Labor Share." Quarterly Journal of Economics.

Oliner, Stephen D. and Daniel E. Sichel. 2000. "The Resurgence of Growth in the Late 1990s: Is Information Technology the Story?" Journal of Economic Perspectives, 14(4), 3-22.

Solow, Robert. 1987. "We'd better watch out." New York Times Book Review, July 12, p 36.

Stiroh, Kevin J. 2002. "Information Technology and the U.S. Productivity Revival: What Do the Industry Data Say?" American Economic Review, 92(5), 1559-1576. 


\section{Appendix}

\subsection{Data Construction: Employment, Output, and Productivity}

Our industry-level employment, output, and productivity outcomes are derived from the NBER-CES Manufacturing Industry Database, which is based largely on the Annual Surveys of Manufacturing (Becker, Gray and Marvakov 2013). ${ }^{8}$ Because this database straddles the 1997 conversion from SIC industry codes to NAICS codes, the providers of the NBER-CES publish both a version expressed in 1987 SIC codes and a version expressed in 1997 NAICS codes.

To minimize the risk of classification error, we aggregate the NBER-CES to the level of 387 consistent industries. ${ }^{9}$ First, we use a weighted crosswalk to convert the NAICS-based data from the years 1997-2009 into 1987 SIC codes, and append the SIC-based data from the years 1977-1996. Second, we map SIC codes into a set of consistent industry codes based on the "SIC87dd" codes used in Autor, Dorn, and Hanson (2013) and in Acemoglu et al. (2013). ${ }^{10}$

Construction of the shipments deflator must be handled carefully due to the cross-walking and aggregation. We compute real shipments separately in the SIC- and NAICS-based NBER-CES files, using the provided shipments deflator ("piship"). Because real and nominal shipments are quantities rather than prices, they can readily be mapped into SIC87dd codes. We then construct the shipments deflator for each SIC87dd industry as the ratio of nominal shipments to real shipments. This procedure is algebraically equivalent to computing the shipments deflator for each SIC87dd industry as a weighted average of the shipments deflators in the SIC/NAICS industries that comprise it, using deflated shipments as the weights. We normalize all shipments deflators to unity in 2007.

For Figure A.5 of this appendix, we compute TFP by implementing the NBER-CES "fourfactor" method, which subtracts cost-share-weighted growth in non-production labor, production labor, materials, and capital inputs from the growth rate of real shipments. A factor's cost share for a given industry is estimated as payments to that factor divided by real shipments, averaged between the current and previous year (with the capital share computed as a residual so that the shares sum to unity). The price deflator for material inputs (based on the NBER-CES "pimat" variable) is constructed in the same fashion as the shipments deflator.

Because we focus on productivity growth within IT-using rather than IT-producing industries, most of our results (except Figure 1A) exclude a set of computer-producing industries. Following Houseman, Bartik, and Sturgeon (2013), we define the computer-producing sector as NAICS 334.

\footnotetext{
${ }^{8}$ While most of the variables in the NBER-CES are taken from the Annual Surveys of Manufacturing, price deflators and depreciation rates are derived from other data published by the Census Bureau, the Bureau of Economic Analysis, the Bureau of Labor Statistics, and the Federal Reserve Board. NBER-CES data and documentation are available at http://www.nber.org/nberces.

${ }^{9}$ We exclude six industries that were reclassified from manufacturing into non-manufacturing following the conversion to NAICS codes (and are therefore absent from the NBER-CES database after 1996). The 1987 SIC codes for these industries are 2411 (logging), 2711, 2721, 2731, 2741, and 2771 (publishing industries). Aside from these exclusions, our sample spans the entire manufacturing sector.

${ }^{10}$ Our NAICS-SIC crosswalk is based on "cw_n97_s87.dta," which can be downloaded from David Dorn's webpage (http://www.cemfi.es/ dorn/data.htm). The mapping from SIC codes into SIC87dd codes is based on "subfile_sic87dd.do," available at the same webpage.
} 
By mapping these NAICS industries into our final set of 387 consistent industries, we were able to identify a set of 28 SIC87dd industries that together constitute virtually a one-to-one correspondence with NAICS 334. ${ }^{11}$ Our set of computer industries encompasses semiconductors and other computer components as well as computer manufacturing proper.

Table A.1 reports the mean and standard deviation of each of our principal outcome variables at decadal intervals, both for our full sample and for a restricted sample of industries in SIC 34-38 (for which data on technology usage are available; further details are given below). For our preferred productivity measure, real shipments per worker, we report summary statistics both including and excluding computer-producing industries. As documented previously by Houseman and coauthors, excluding these industries noticeably reduces the measured rate of productivity growth in manufacturing. For the remaining outcomes, we report summary statistics only for non-computer-producing industries (as computer industries have considerably less influence on the evolution of manufacturing output and employment when these outcomes are examined separately).

\subsection{Data Construction: IT Intensity}

We employ two measures of industry-level IT intensity: rates of computer investment, and usage of a set of manufacturing technologies.

We observe each industry's expenditures on computers and peripheral equipment for the years 1977, 1982, 1987, 1992, 2002, and 2007 (comparable data are not available for 1997). ${ }^{12}$ After mapping all computer investment data into SIC87dd codes, ${ }^{13}$ we define an industry's raw computer investment rate as 100 times the ratio of its computer expenditures to its total capital expenditures. We impute a small number of missing values. ${ }^{14}$ Our preferred measure of computer investment rates is a weighted average of the 1977, 1982, 1987, 1992, 2002, and 2007 rates. To account for the unavailability of 1997 computer investment rates, we place weight 5/32 on the 1977-1992 rates and weight $3 / 16$ on the 2002 and 2007 rates (so that the weighted average year is 1992, the midpoint of 1977-2007). We also report results using 1977/1982 rates, 1987/1992 rates, and 2002/2007 rates (in each case computing the simple average of computer investment rates in the indicated years).

Our measure of technology usage is derived from the US Census Bureau's 1988 and 1993 Sur-

\footnotetext{
${ }^{11}$ Specifically, our computer sector accounts for over $98 \%$ of NAICS 334 employment throughout our sample period, and our non-computer sector accounts for over $99 \%$ of non-NAICS 334 employment throughout our sample period.

${ }^{12}$ Computer investment data for 1977, 1982, and 1987 were provided to us by Eli Berman. Data for 1992 were transcribed from the manufacturing industry series at http://www.census.gov/prod/www/economic_census.html. Data for 2002 and 2007 were downloaded using the US Census Bureau's American FactFinder tool (tables EC0231I3 and EC0731I1, respectively).

${ }^{13}$ The data for 1977, 1982, and 1987 are expressed in 1972 SIC codes; 1992 data are expressed in 1987 SIC codes; 2002 data are expressed in 2002 NAICS codes; and 2007 data are expressed in 2007 NAICS codes. We apply crosswalks sequentially to map data into SIC87dd codes. The 1972-1987 SIC crosswalk is downloaded from http://www.nber.org/nberces. The 2002-1997 NAICS crosswalk is downloaded from http://www.census.gov/econ/census02/data/bridge. The 2007-2002 NAICS crosswalk is downloaded from American FactFinder (table EC0700CBDG1).

${ }^{14}$ Computer investment data are available for all 387 SIC87dd industries in the years 1977, 1982, 1987 , and 2002. We impute missing 1992 values for 27 industries by linearly interpolating their 1987 and 2002 computer investment rates. We impute missing 2007 values for two industries by extrapolating from their 2002 computer investment rates using manufacturing-wide changes in computer investment rates between 2002 and 2007.
} 
veys of Manufacturing Technology (SMT), which queries manufacturing plants on their usage of 17 advanced manufacturing technologies. ${ }^{15}$ Our SMT measure of IT intensity is defined as the employment-share-weighted fraction of these 17 technologies used by plants within an industry, averaged between the 1988 and 1993 surveys. ${ }^{16}$ Presumably because of the specialized nature of the survey questions, SMT data are available only for the 148 SIC87dd industries that comprise SIC codes 34-38 (with the number of industries falling to 120 when we exclude computer-producing industries). All analyses using SMT data are conducted on this reduced set of industries.

Table A.2 provides summary statistics for each of our IT measures. Table A.3 reports the correlation between each pair of IT measures. In keeping with our implicit assumption that computer investment rates proxy for "permanent" differences in industries' susceptibility to computerization, these rates are positively correlated over time. Consistent with our concerns stated in the text regarding the best way to measure IT-intensity, computer investment rates are uncorrelated with our measure of technology usage in the restricted set of industries for which SMT data are available.

To facilitate comparison of estimated coefficients across different measures of IT intensity, we standardize all IT measures to have zero mean and unit standard deviation across employmentweighted industries.

\subsection{Additional Results using Main Regression Specification}

The figures at the end of this appendix perform additional analyses that do not appear in the main body of the paper. As per equation (1), our regression model takes the form

$$
\log Y_{j t}=\gamma_{\mathbf{j}}+\delta_{\mathbf{t}}+\sum_{t=81}^{09} \beta_{t} \times I T_{j}+e_{j t},
$$

where $\log Y$ is 100 times the $\log$ of an outcome of interest, $\gamma$ is a vector of industry fixed effects, $\delta$ is a vector of time dummies, IT is a static measure of industry IT-intensity, and $e$ is an error term. This specification normalizes the coefficient on the IT variable to zero in the base year, and hence the series $\left\{\beta_{81}, \beta_{82}, \ldots, \beta_{09}\right\}$ may be read as the level of the coefficient on IT in each subsequent year relative to 1980 .

A priori, it is possible that an IT investment measure that focused on the most recent years of IT investments - rather than averaging over three decades - might prove more predictive of recent

\footnotetext{
${ }^{15}$ SMT data were used by Doms, Dunne, and Troske (1997) in their plant-level analysis of technology and skill upgrading in manufacturing. Kenneth Troske generously aggregated these confidential plant-level data to the industry level for use by other researchers. The 17 technologies included in the SMT are automatic guided vehicle systems; automatic sensors used on inputs; automatic sensors used on final products; automatic storage/retrieval systems; computer aided design (CAD); CAD controlled machines; digital CAD; technical data network; factory network; intercompany network; programmable controllers; computers used on the factory floor; numerically controlled machines; flexible manufacturing systems/cells; material working lasers; pick and place robots; and other robots. See Doms, Dunne and Troske (1997) for further details on the SMT data.

${ }^{16}$ The 1988 SMT data are expressed in 1977 SIC codes, while the 1993 SMT data are expressed in 1987 SIC codes. We convert the 1988 data into 1987 SIC codes using the crosswalk at http://www.census.gov/epcd/www/SIC1987\%20to\%20SIC1977\%20correspondence\%20tables.pdf, and then aggregate the 1988 and 1993 data to the level of SIC87dd industries.
} 
industry-level changes in productivity, output, and employment since such a measure would better reflect the current locus of the IT frontier. As a check on this possibility, Figures A.1 through A.4 explore the relationship between IT and productivity, output, and employment using several different vintages of our computer investment variable. In each of these figures, the 1977-2007 series uses computer investment rates averaged over 1977, 1982, 1987, 1992, 2002, and 2007, as described above. The remaining series use computer investment rates averaged between the indicated years. All of these measures have been standardized to have zero mean and unit standard deviation across employment-weighted industries.

Figure A.1 suggests that the choice of vintage does not qualitatively affect our results on labor productivity. Each of the three vintages shown (1977/1982, 1987/1992, and 2002/2007) indicates that IT-intensive industries experienced relatively faster productivity growth during the late 1990s but not during the 2000s. The strongest evidence for a late 1990s productivity boom actually comes from the oldest computer investment data (1977/1982), suggesting that attenuation bias is unlikely to be driving our findings. Similar statements apply to our results on output and employment. Figures A.2, A.3, and A.4 show that IT-intensive industries have experienced relative declines in real shipments, nominal shipments, and employment since 1990. These figures provide some reassurance that our results are not sensitive to the precise timing of the IT measure.

Supplementing the outcomes investigated in the main text of the paper, Figures A.5, A.6, A.7, and A.8 explore the connection between IT intensity and four additional outcomes: TFP, nominal value added, the shipments deflator, and the wage bills paid to non-production and production workers.

Our TFP results (Figure A.5) reveal no evidence of relatively faster productivity growth in ITusing industries. When measured by technology usage, IT intensity is essentially uncorrelated with TFP growth between 1990 and 2009. When measured by computer investments, IT intensity is actually negatively correlated with TFP growth over this period. While we prefer real shipments per worker as a measure of productivity (since TFP relies on potentially erroneous input price deflators), these results underscore the non-robustness of the relationship between IT and productivity in manufacturing industries.

The results for nominal value added (Figure A.6) parallel those for real and nominal shipments. Using either measure of IT intensity (computer investments or technology usage), IT-intensive industries experienced relative declines in nominal value added beginning in the early 1990s. Although real and nominal shipments are our preferred output measures because they are not susceptible to problems arising from changes in input deflators, it is reassuring that nominal value added yields similar conclusions.

In Figure A.7, we find no evidence that IT-intensive industries have experienced relative declines in their shipments deflators (i.e., output prices). This is a surprising result: if IT allows firms to lower production costs, one would expect prices to fall in IT-intensive industries. It is theoretically possible, however, that declining production costs are offset by increases in product quality that cannot be detected in our data. 
Finally, Figure A.8 provides ambiguous evidence on the relationship between IT and skill intensity. While both computer investments and technology usage are associated with declines in the wage bill paid to both non-production and production labor, the measures disagree as to whether IT-using industries experience steeper declines in non-production or in production labor. Panel A confirms the earlier finding of Berman, Bound, and Griliches (1994) and subsequent authors that rates of computer investment are positively correlated with the ratio of non-production labor to production labor. Panel B shows, if anything, the opposite result when IT is measured by technology usage. ${ }^{17}$ A possible explanation for these contradictory findings is that IT may complement some types of non-production workers (such as managers) while substituting for others (such as clerical workers). Computer investments and technology usage may differ in the relative strength of these complementarities and substition effects.

\subsection{Results using Changes in the Rate of Computer Investment}

As a final exercise, Table A.4 addresses the possibility that changes in the rate of computer investment may be more predictive of productivity growth and output growth than the levels of this rate. The ratio of computer investments to total capital expenditures may be influenced by factors that have little to do with an industry's susceptibility to computerization, such as the depreciation rate of its non-computer capital. For each of our core outcomes, we therefore run a regression of the form

$$
\Delta \log Y_{j t}=\delta_{\mathbf{t}}+\beta \times \Delta I T_{j t}+e_{j t},
$$

where $\log Y$ is 100 times the $\log$ of an outcome of interest, IT is 100 times the ratio of computer investments to total investments, the $\Delta$ operator signifies annualized changes over 5- or 10-year periods, and $\delta$ is a full set of time effects. In a departure from the rest of the paper, the computer investment rate used here is not standardized to have zero mean and unit standard deviation (results are qualitatively similar when we use standardized measures). We pool annualized changes over the periods 1977-1982, 1982-1987, 1987-1992, 1992-2002, and 2002-2007. Except for column (1), all specifications exclude computer-producing industries.

The results provide little indication that changes in the rate of computer investment are predictive of productivity or output growth. Columns (1) and (2) show that changes in real shipments per worker are actually slightly negative correlated with changes in computer investment, whether or not we exclude computer-producing industries. ${ }^{18}$ Changes in real shipments, nominal shipments, employment, and wage bills are uncorrelated with changes in the rate of computer investment. We do however find that industries experiencing faster growth in computer investments also experience

\footnotetext{
${ }^{17}$ Although Panel A and Panel B are estimated on different samples (with Panel B restricted to SIC 34-38), unreported results using computer investment rates in the restricted SIC 34-38 sample are qualitatively similar to Panel A.

${ }^{18}$ Unlike Figure 1A, where excluding the computer sector substantially dampens the positive correlation between computer investments and productivity growth, doing so here actually leads to a less-negative correlation between changes in the rate of computer investment and changes in productivity. These findings can be reconciled by noting that computer-producing industries experienced relatively sluggish growth (and sometimes declines) in the rate of computer investment over the period 1977-2007.
} 
modestly faster growth in their use of non-production labor (with little change in their use of production labor), a finding consistent with our evidence of skill upgrading in Panel A of Figure A.8.

\section{A Appendix Figures and Tables}

Figure A.1: Computer Investment Rates and Log Real Shipments per Worker, 1980-2009

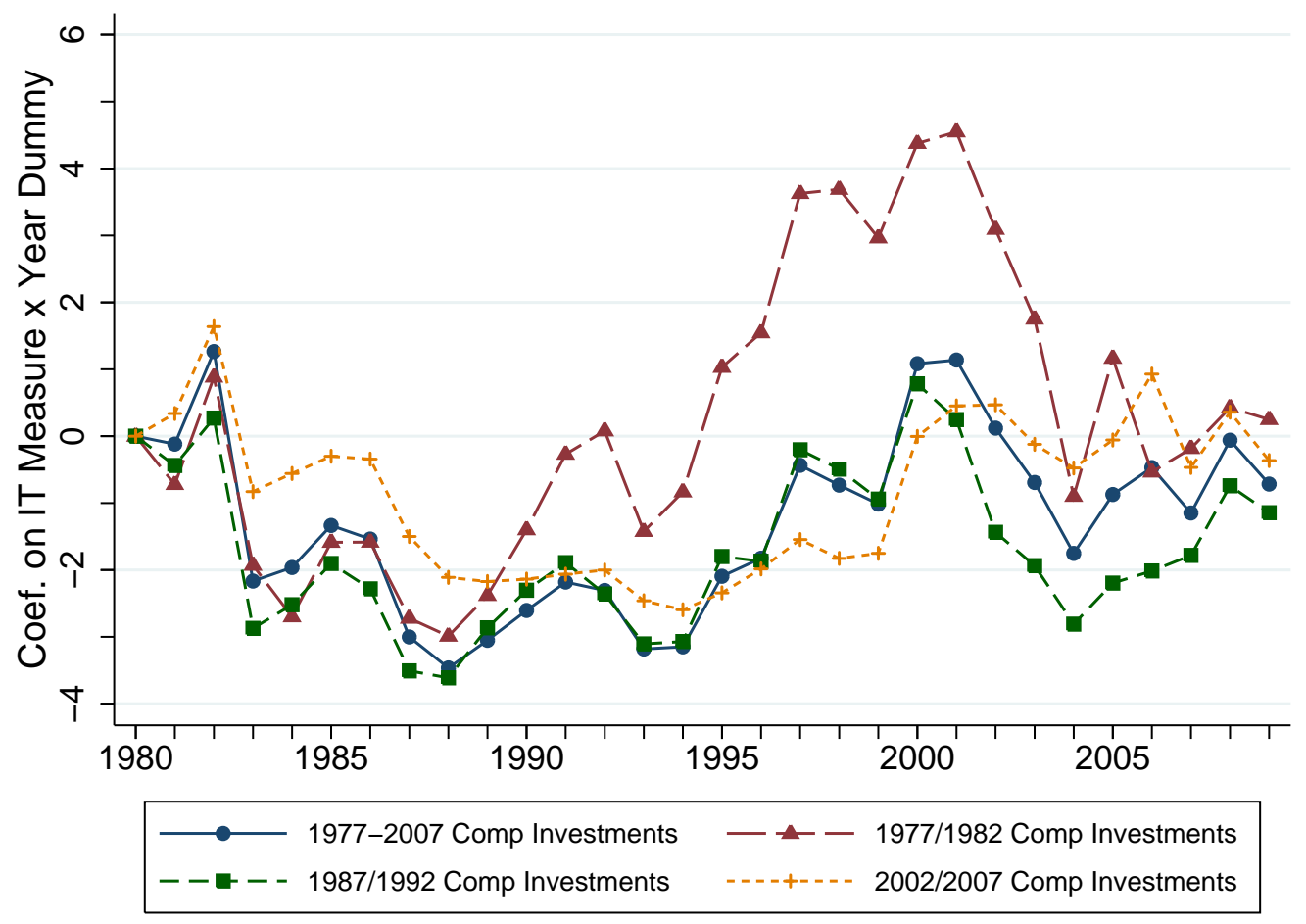

Notes: Coefficients from regressions of $100 \times$ log real shipments per worker on measures of IT intensity. The sample consists of 359 non-computer-producing manufacturing industries, observed at annual frequency over 1980-2009. Each industry's IT intensity is defined as the ratio of its computer investments to its total investments, averaged over the indicated years. The 1977-2007 series averages this ratio over the years 1977, 1982, 1987, 1992, 2002 and 2007 (no 1997 measure is available), placing slightly greater weight on the last two periods to compensate for the absence of the 1997 measure). For the remaining series, we take the simple average of the computer investment ratios in the indicated years. Each measure of IT intensity is then standardized so that the final measure has zero mean and unit standard deviation across employment-weighted industries. Real shipments are expressed in constant dollars using industry-specific price deflators. We regress 100 $\mathrm{x} \log$ real shipments per worker on industry fixed effects, year effects, and IT intensity x year interactions (omitting the 1980 interaction). Industries are weighted by their average share of total manufacturing employment over the sample period. 
Figure A.2: Computer Investment Rates and Log Real Shipments, 1980-2009

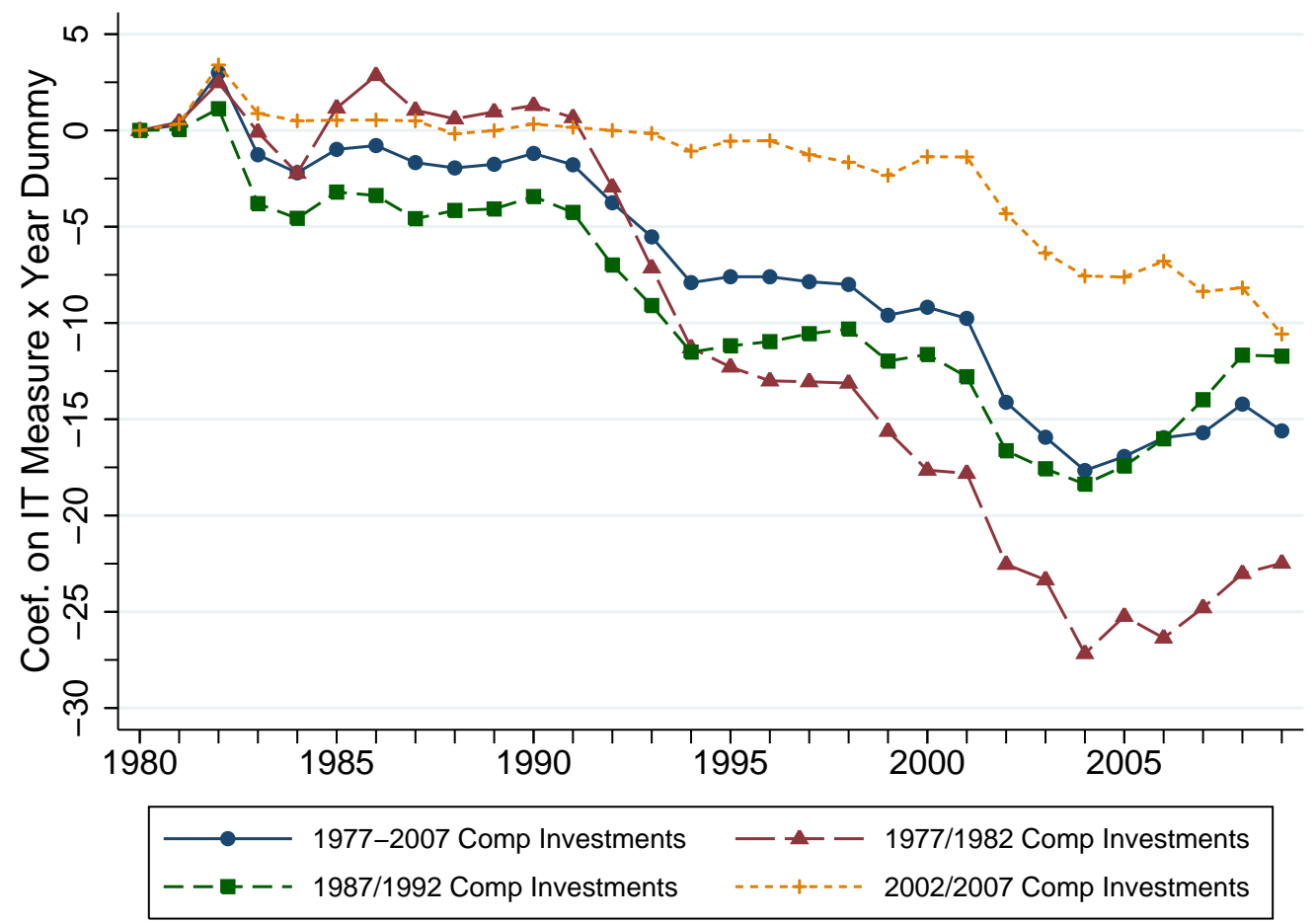

Notes: See Figure A.1 for details. 
Figure A.3: Computer Investment Rates and Log Nominal Shipments, 1980-2009

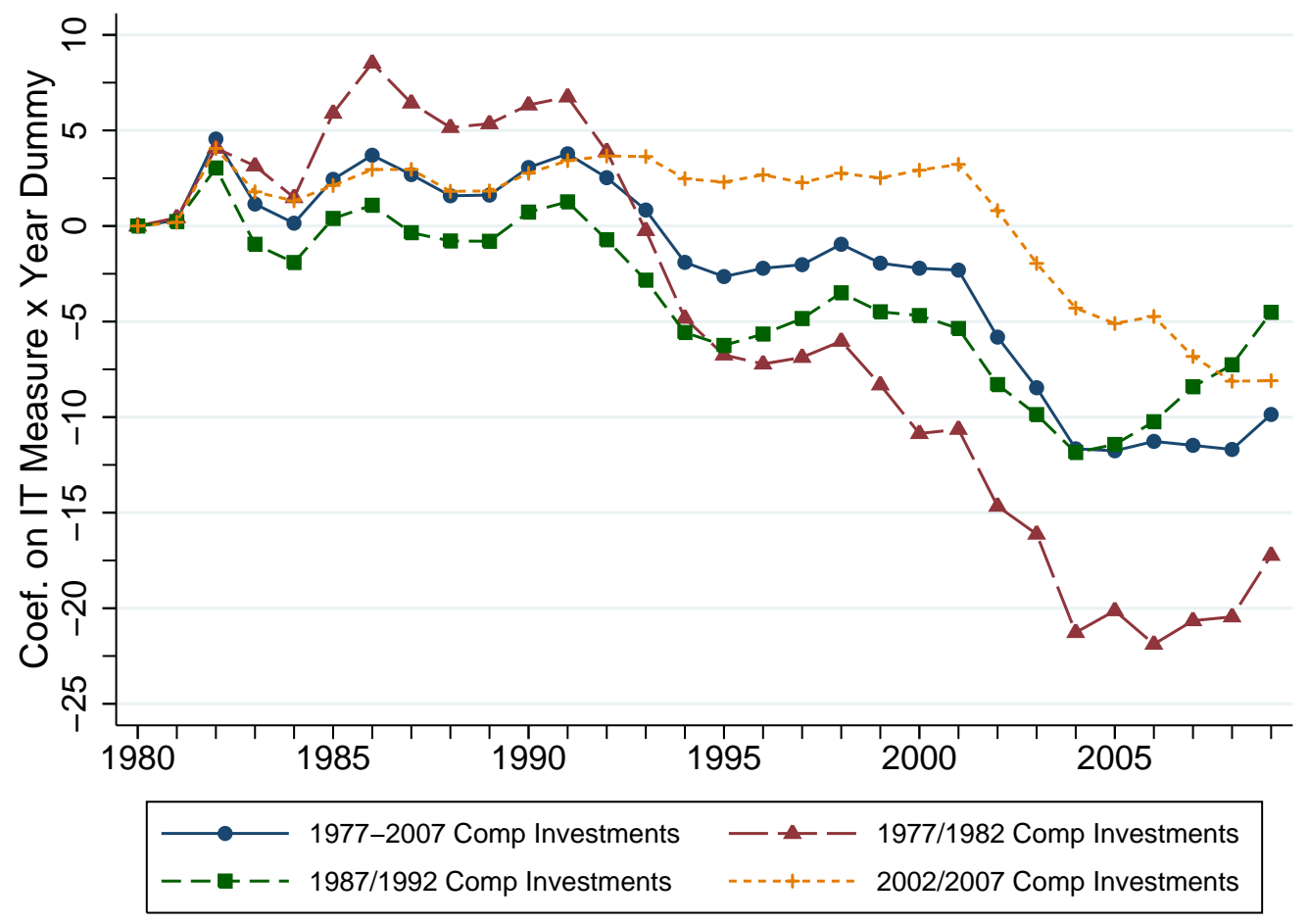

Notes: See Figure A.1 for details. 
Figure A.4: Computer Investment Rates and Log Employment, 1980-2009

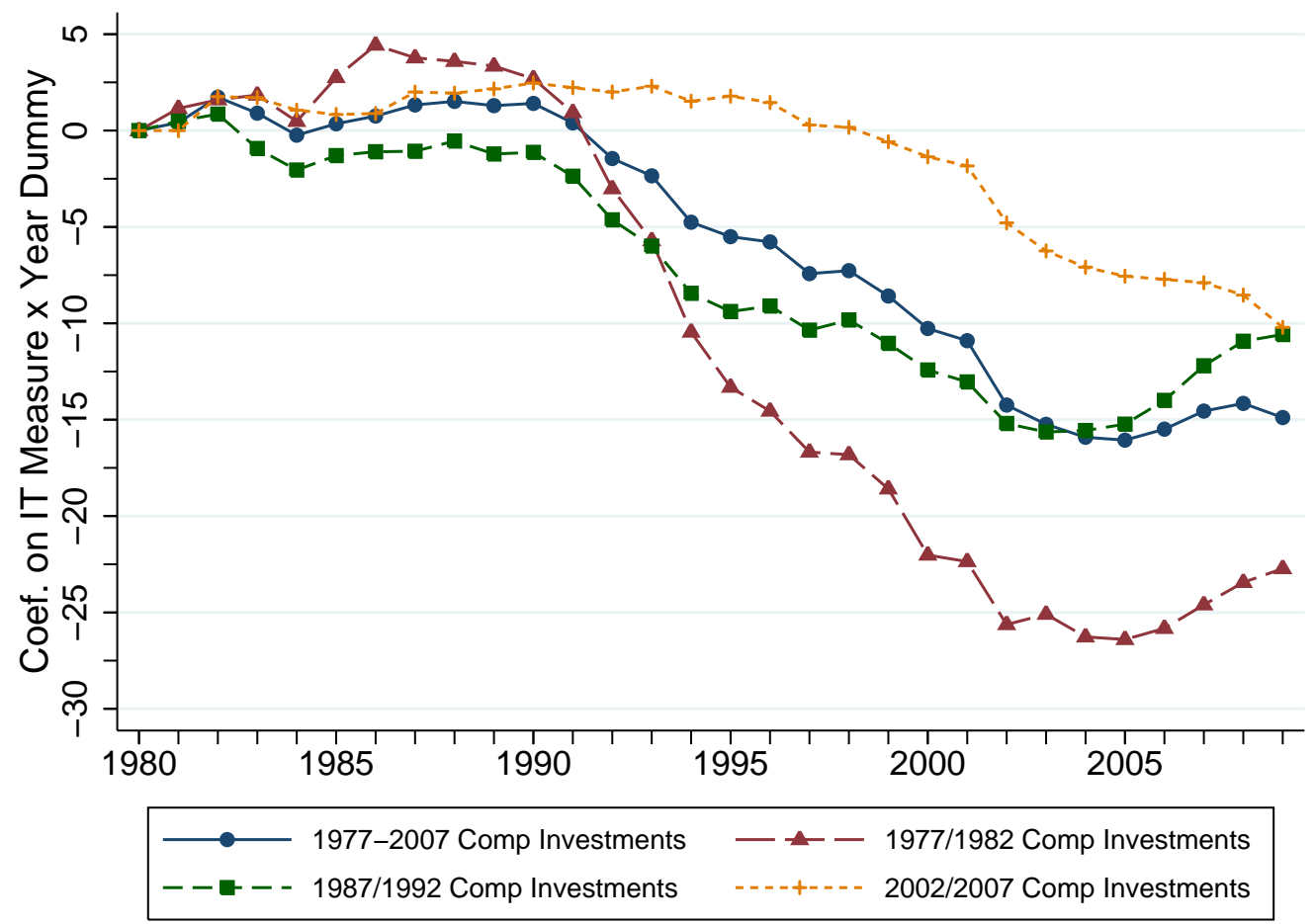

Notes: See Figure A.1 for details. 
Figure A.5: IT Measures and Log TFP, 1980-2009

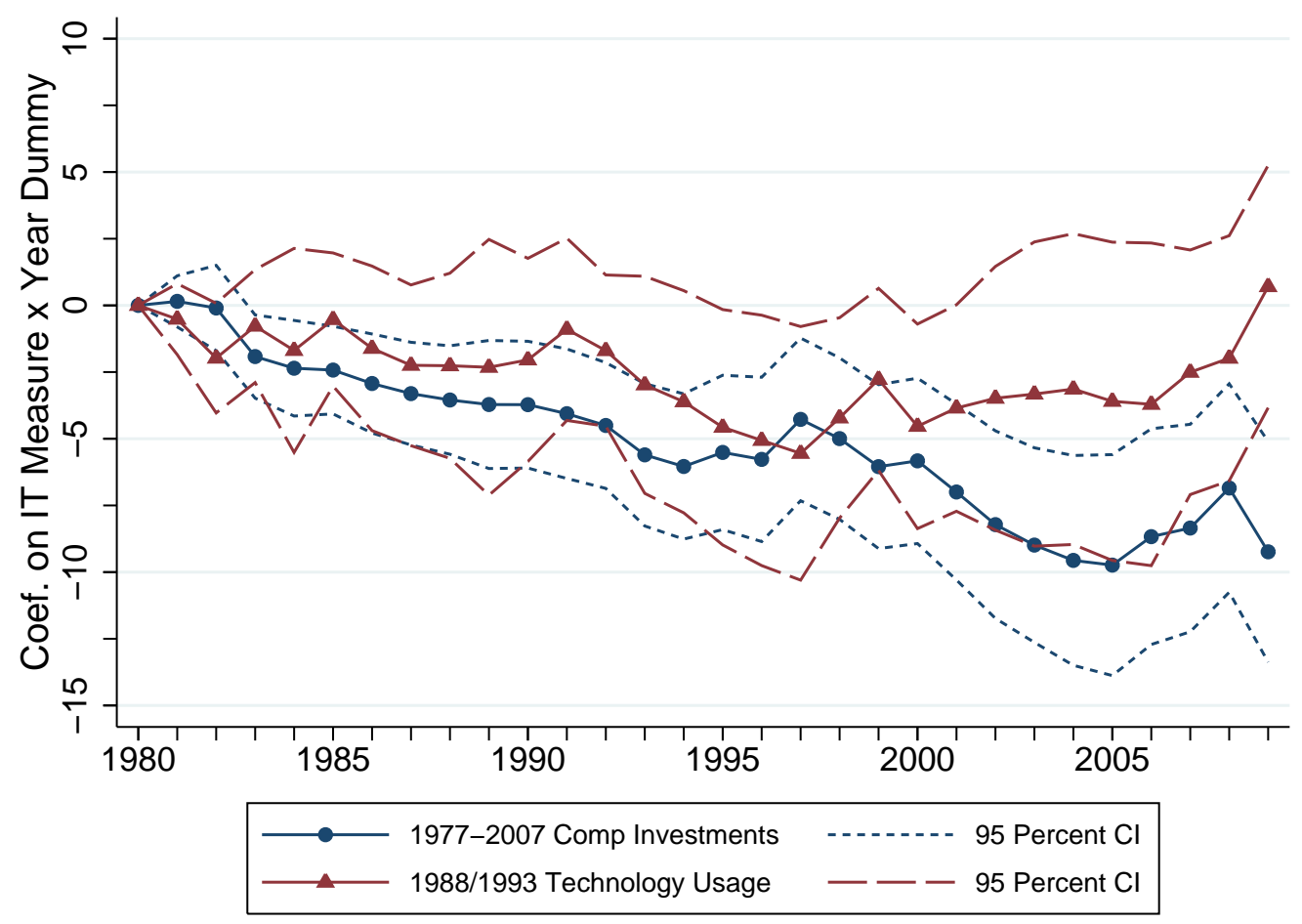

Notes: Coefficients from regressions of $100 \mathrm{x} \log$ TFP on measures of IT intensity. For the series labeled "1977-2007 Comp Investments," the sample consists of 359 non-computer-producing manufacturing industries. For the series labeled "1988/1993 Technology Usage," the sample consists of 120 non-computer-producing manufacturing industries that fall within SIC codes 34-38. In the technology usage series, an industry's IT intensity is defined as the employment-weighted share of 17 advanced manufacturing technologies used by plants within that industry. As with the computer investment measure, the technology usage measure is standardized to have zero mean and unit standard deviation across employment-weighted industries. The regression specification parallels that used throughout the paper. The 95-percent confidence intervals are based on standard errors clustered on industry. See Figure 1 of the paper for further details. 
Figure A.6: IT Measures and Log Nominal Value Added, 1980-2009

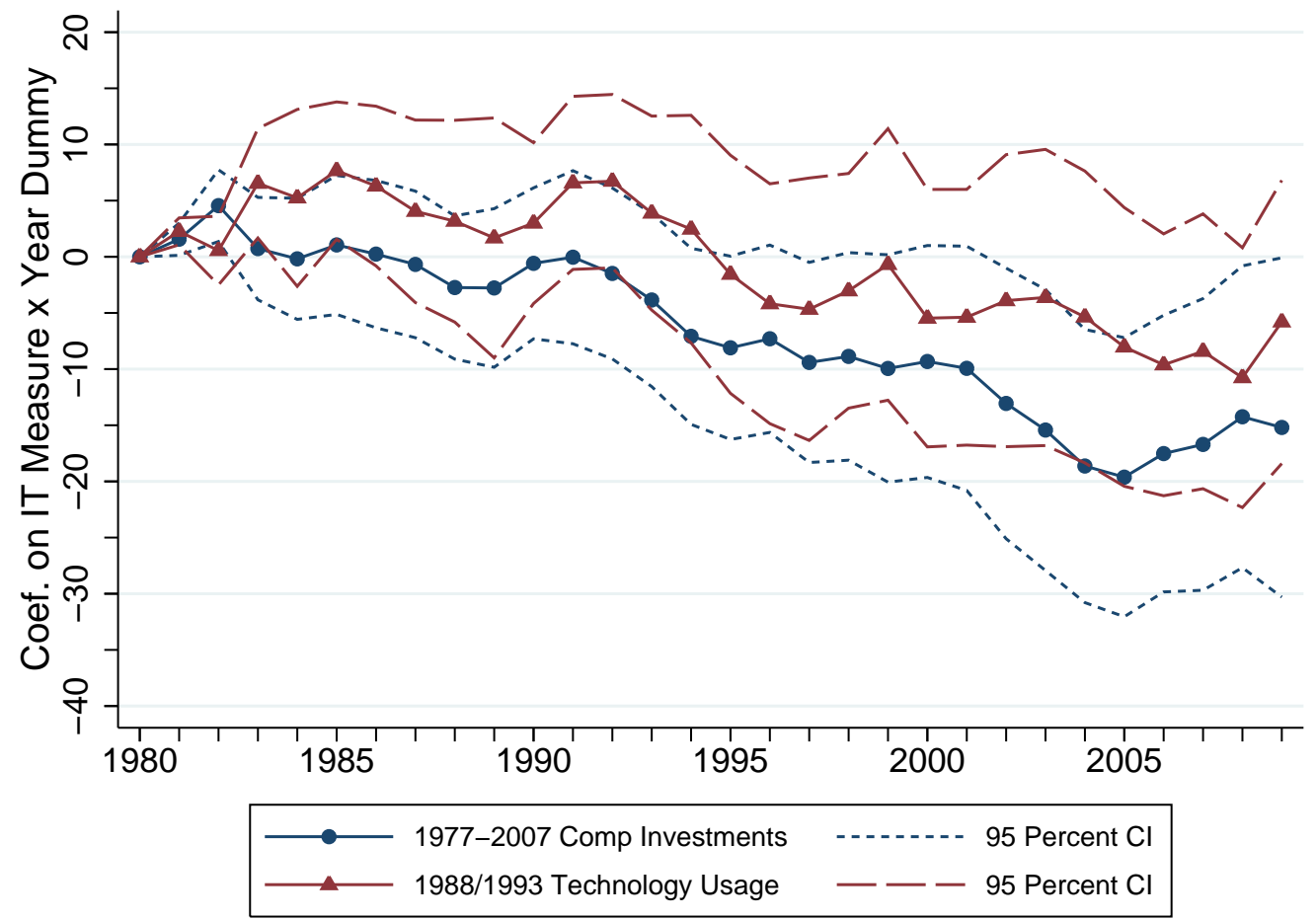

Notes: Nominal value added is computed as nominal shipments minus the nominal cost of materials. See Figure A.5 for details on the regression specifications underlying this figure. 
Figure A.7: IT Measures and Log Shipments Deflator, 1980-2009

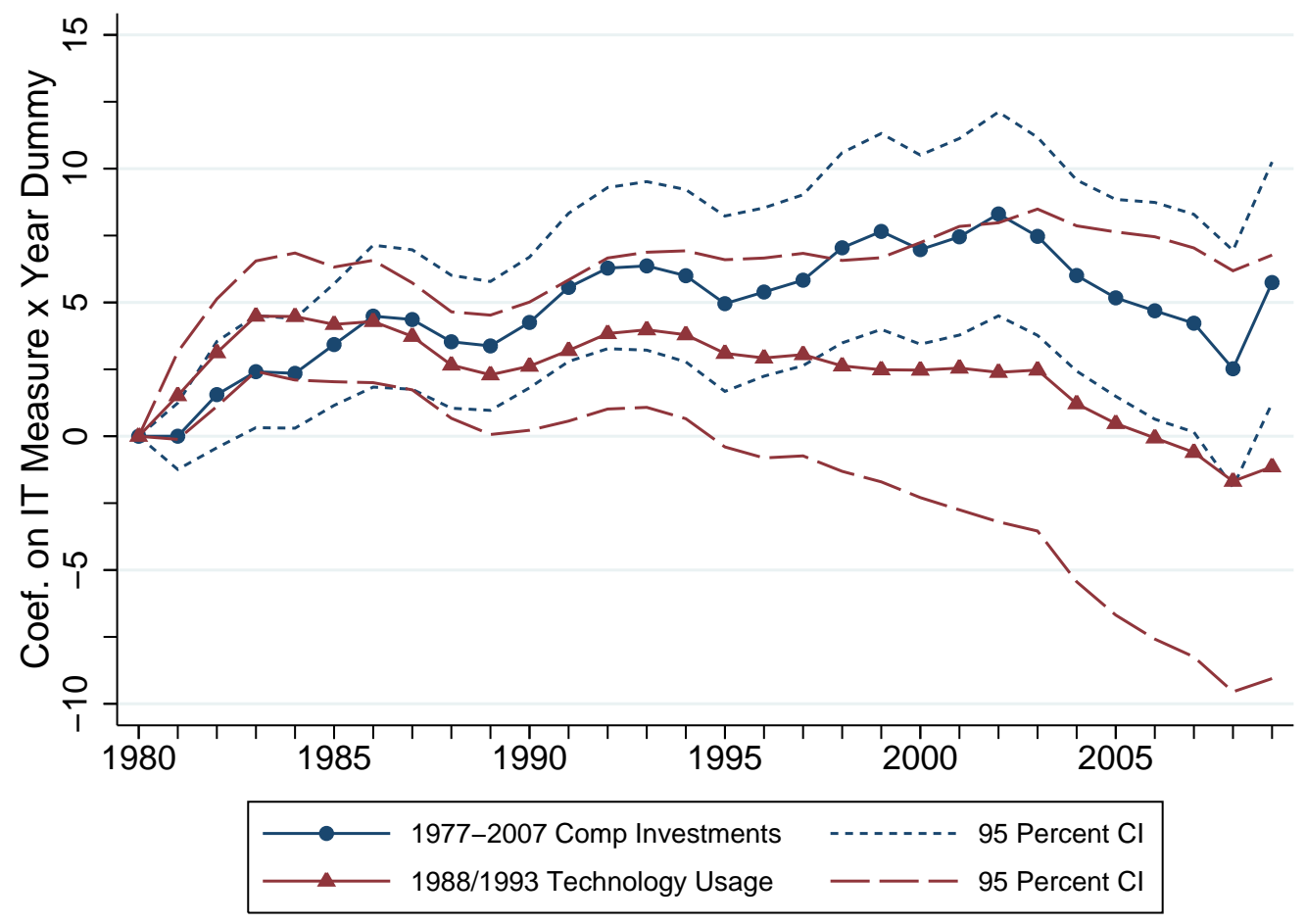

Notes: See the text of this appendix for details on the construction of the shipments deflator. See Figure A.5 for details on the regression specifications underlying this figure.

Figure A.8: IT Measures and Log Non-Production and Production Worker Wage Bills, 1980-2009
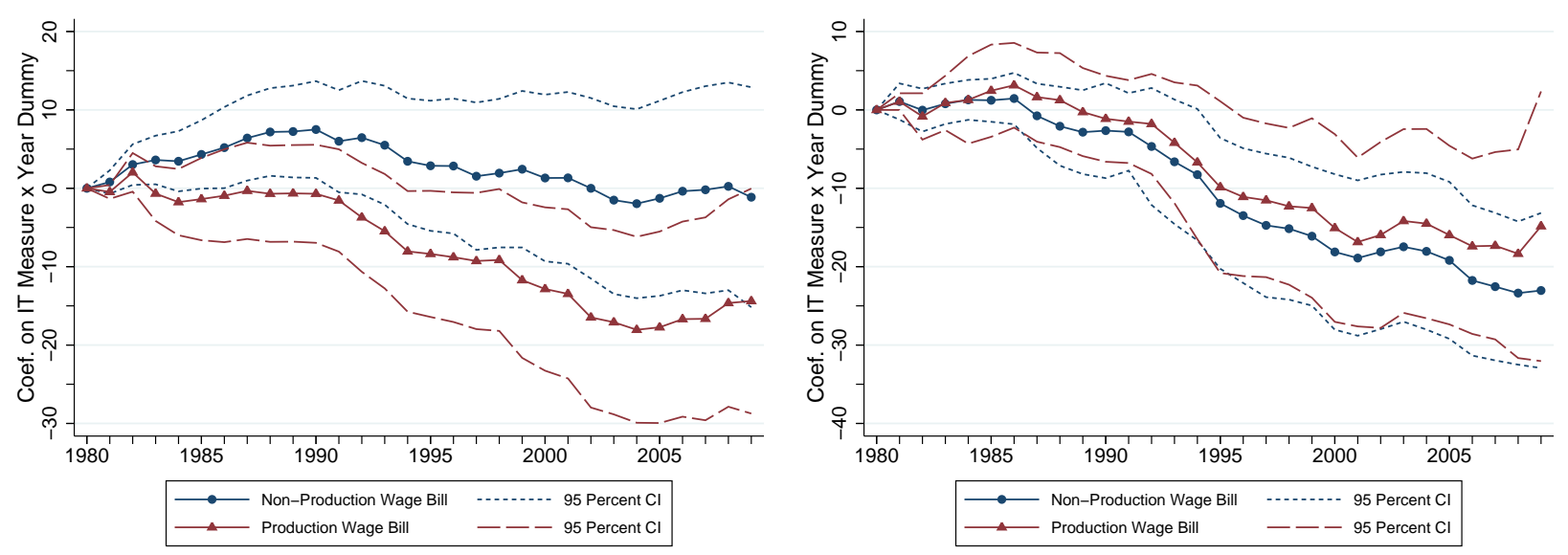

Notes: Panel A defines IT intensity on the basis of 1977-2007 computer investments. Panel B defines IT intensity on the basis of 1988/1993 technology usage. See Figure A.5 for additional details. 
Table A.1: Means and Standard Deviations of Key Outcome Variables

\begin{tabular}{|c|c|c|c|c|c|c|c|c|c|c|}
\hline & \multicolumn{5}{|c|}{ Full Sample } & \multicolumn{5}{|c|}{ Restricted Sample (SICs 34-38) } \\
\hline & $\mathrm{N}$ & 1980 & 1990 & 2000 & 2009 & $\mathrm{~N}$ & 1980 & 1990 & 2000 & 2009 \\
\hline $\begin{array}{l}\text { Log Real Shipments/Worker } \\
\text { (Including Computer Sector) }\end{array}$ & 387 & $\begin{array}{l}4.80 \\
(0.96)\end{array}$ & $\begin{array}{l}5.10 \\
(0.81)\end{array}$ & $\begin{array}{c}5.46 \\
(0.60)\end{array}$ & $\begin{array}{c}5.66 \\
(0.64)\end{array}$ & 148 & $\begin{array}{c}4.58 \\
(1.12)\end{array}$ & $\begin{array}{c}4.92 \\
(0.84)\end{array}$ & $\begin{array}{c}5.44 \\
(0.43)\end{array}$ & $\begin{array}{c}5.67 \\
(0.49)\end{array}$ \\
\hline $\begin{array}{l}\text { Log Real Shipments/Worker } \\
\text { (Excluding Computer Sector) }\end{array}$ & 359 & $\begin{array}{c}4.97 \\
(0.64)\end{array}$ & $\begin{array}{c}5.21 \\
(0.65)\end{array}$ & $\begin{array}{c}5.48 \\
(0.62)\end{array}$ & $\begin{array}{c}5.64 \\
(0.65)\end{array}$ & 120 & $\begin{array}{c}4.93 \\
(0.38)\end{array}$ & $\begin{array}{c}5.15 \\
(0.41)\end{array}$ & $\begin{array}{c}5.47 \\
(0.45)\end{array}$ & $\begin{array}{c}5.62 \\
(0.46)\end{array}$ \\
\hline Log Real Shipments & 359 & $\begin{array}{c}9.39 \\
(1.19)\end{array}$ & $\begin{array}{c}9.57 \\
(1.23)\end{array}$ & $\begin{array}{c}9.82 \\
(1.30)\end{array}$ & $\begin{array}{c}9.53 \\
(1.47)\end{array}$ & 120 & $\begin{array}{c}9.43 \\
(1.10)\end{array}$ & $\begin{array}{c}9.55 \\
(1.13)\end{array}$ & $\begin{array}{c}9.87 \\
(1.21)\end{array}$ & $\begin{array}{c}9.64 \\
(1.20)\end{array}$ \\
\hline Log Nominal Shipments & 359 & $\begin{array}{c}8.78 \\
(1.17)\end{array}$ & $\begin{array}{c}9.28 \\
(1.22)\end{array}$ & $\begin{array}{c}9.67 \\
(1.29)\end{array}$ & $\begin{array}{c}9.56 \\
(1.46)\end{array}$ & 120 & $\begin{array}{c}8.80 \\
(1.11)\end{array}$ & $\begin{array}{c}9.27 \\
(1.18)\end{array}$ & $\begin{array}{c}9.72 \\
(1.24)\end{array}$ & $\begin{array}{c}9.70 \\
(1.19)\end{array}$ \\
\hline Log Employment & 359 & $\begin{array}{c}4.43 \\
(1.07)\end{array}$ & $\begin{array}{c}4.36 \\
(1.13)\end{array}$ & $\begin{array}{c}4.34 \\
(1.21)\end{array}$ & $\begin{array}{c}3.89 \\
(1.29)\end{array}$ & 120 & $\begin{array}{c}4.50 \\
(0.98)\end{array}$ & $\begin{array}{c}4.40 \\
(1.04)\end{array}$ & $\begin{array}{c}4.39 \\
(1.09)\end{array}$ & $\begin{array}{c}4.03 \\
(1.08)\end{array}$ \\
\hline Log Real Wage Bill & 359 & $\begin{array}{c}7.99 \\
(1.14)\end{array}$ & $\begin{array}{c}7.97 \\
(1.18)\end{array}$ & $\begin{array}{c}8.06 \\
(1.25)\end{array}$ & $\begin{array}{c}7.65 \\
(1.36)\end{array}$ & 120 & $\begin{array}{c}8.20 \\
(1.07)\end{array}$ & $\begin{array}{c}8.15 \\
(1.12)\end{array}$ & $\begin{array}{c}8.24 \\
(1.15)\end{array}$ & $\begin{array}{c}7.91 \\
(1.11)\end{array}$ \\
\hline
\end{tabular}

Notes: Real shipments are deflated to 2007 dollars using industry-specific price deflators; real wage bill is deflated to 2007 dollars using the Personal Consumption Expenditures series. Real shipments, nominal shipments, and real wage bill are expressed in millions of dollars; employment is expressed in thousands; and real shipments per worker is expressed in thousands of dollars. All calculations are weighted by industries' average share of manufacturing employment over 1980-2009.

Table A.2: Summary Statistics for Measures of Investment Technology

\begin{tabular}{|c|c|c|c|c|c|c|c|c|c|c|}
\hline & \multicolumn{5}{|c|}{ Including Computer-Producing Industries } & \multicolumn{5}{|c|}{ Excluding Computer-Producing Industries } \\
\hline & $\mathrm{N}$ & $\begin{array}{c}\text { Mean } \\
\text { (SD) }\end{array}$ & Median & Min & Max & $\mathrm{N}$ & $\begin{array}{c}\text { Mean } \\
(\mathrm{SD})\end{array}$ & Median & Min & Max \\
\hline 1977-2007 Computer Investments & 387 & $\begin{array}{c}5.65 \\
(3.80)\end{array}$ & 5.07 & 0.46 & 22.58 & 359 & $\begin{array}{c}4.95 \\
(2.95)\end{array}$ & 4.55 & 0.46 & 16.62 \\
\hline 1977/1982 Computer Investments & 387 & $\begin{array}{c}2.74 \\
(3.40)\end{array}$ & 1.82 & 0.00 & 28.24 & 359 & $\begin{array}{c}2.14 \\
(2.02)\end{array}$ & 1.55 & 0.00 & 17.37 \\
\hline 1987/1992 Computer Investments & 387 & $\begin{array}{c}7.25 \\
(6.16)\end{array}$ & 5.78 & 0.00 & 31.28 & 359 & $\begin{array}{c}6.07 \\
(4.60)\end{array}$ & 4.96 & 0.00 & 28.55 \\
\hline 2002/2007 Computer Investments & 387 & $\begin{array}{c}6.73 \\
(4.01)\end{array}$ & 5.95 & 0.00 & 23.50 & 359 & $\begin{array}{c}6.37 \\
(3.85)\end{array}$ & 5.71 & 0.00 & 23.50 \\
\hline 1988/1993 Technology Adoption & 148 & $\begin{array}{c}37.75 \\
(14.27)\end{array}$ & 36.57 & 9.96 & 69.39 & 120 & $\begin{array}{c}35.71 \\
(14.71)\end{array}$ & 33.41 & 9.96 & 69.39 \\
\hline
\end{tabular}

Notes: The four computer investment measures are defined as 100 times the ratio of an industry's computer investments to its total investments, averaged over the indicated years. The 1977-2007 series averages this ratio over the years 1977, 1982, 1987, 1992, 2002 and 2007 (no 1997 measure is available), placing slightly greater weight on the last two periods to compensate for the absence of the 1997 measure). For the remaining series, we take the simple average of the computer investment ratios in the indicated years. An industry's technology usage is defined as 100 times the employment-weighted share of 17 advanced manufacturing technologies used by plants within that industry, averaged between 1988 and 1993. The technology usage measure is available only for industries within SIC 34-38. All calculations are weighted by industries' average share of manufacturing employment over 1980-2009. 
Table A.3: Correlations Between IT Measures

\begin{tabular}{lccccc} 
& $\begin{array}{c}1977-2007 \\
\text { Computer } \\
\text { Investments }\end{array}$ & $\begin{array}{c}1977 / 1982 \\
\text { Computer } \\
\text { Investments }\end{array}$ & $\begin{array}{c}1987 / 1992 \\
\text { Computer } \\
\text { Investments }\end{array}$ & $\begin{array}{c}2002 / 2007 \\
\text { Computer } \\
\text { Investments }\end{array}$ & $\begin{array}{c}\text { 1988/1993 } \\
\text { Technology } \\
\text { Adoption }\end{array}$ \\
\hline 1977-2007 Computer Investments & 1.00 & & & & \\
1977/1982 Computer Investments & 0.68 & 1.00 & & & \\
1987/1992 Computer Investments & 0.90 & 0.60 & 1.00 & & \\
2002/2007 Computer Investments & 0.85 & 0.36 & 0.57 & 1.00 & 1.00 \\
1988/1993 Technology Adoption & -0.12 & 0.18 & 0.06 & -0.44 &
\end{tabular}

Notes: Correlations between computer investment measures include all non-computer-producing industries $(\mathrm{n}=359)$. Correlations between computer investments and technology usage include noncomputer-producing industries in SIC 34-38 ( $\mathrm{n}=120)$. All correlations are weighted by industries' average share of manufacturing employment over 1980-2009. See notes for Table A.2 for additional details.

Table A.4: Changes in Computer Investment and Changes in Key Outcomes

\begin{tabular}{|c|c|c|c|c|c|c|c|c|}
\hline & $\begin{array}{c}(1) \\
\text { Real } \\
\text { Shipments / } \\
\text { Worker }\end{array}$ & $\begin{array}{c}(2) \\
\text { Real } \\
\text { Shipments / } \\
\text { Worker }\end{array}$ & $\begin{array}{c}(3) \\
\text { Real } \\
\text { Shipments }\end{array}$ & $\begin{array}{c}(4) \\
\text { Nominal } \\
\text { Shipments }\end{array}$ & Emp & $\begin{array}{c}(6) \\
\text { Real Wage } \\
\text { Bill }\end{array}$ & $\begin{array}{c}(7) \\
\text { Prod Real } \\
\text { Wage Bill }\end{array}$ & $\begin{array}{c}(8) \\
\text { Non-Prod } \\
\text { Real Wage } \\
\text { Bill }\end{array}$ \\
\hline$\Delta$ in Computer Investment Rate & $\begin{array}{c}-0.39^{*} \\
(0.20)\end{array}$ & $\begin{array}{c}-0.14 \\
(0.09)\end{array}$ & $\begin{array}{c}-0.12 \\
(0.17)\end{array}$ & $\begin{array}{c}-0.02 \\
(0.18)\end{array}$ & $\begin{array}{c}0.02 \\
(0.14)\end{array}$ & $\begin{array}{c}0.09 \\
(0.15)\end{array}$ & $\begin{array}{c}-0.13 \\
(0.16)\end{array}$ & $\begin{array}{c}0.33^{* *} \\
(0.15)\end{array}$ \\
\hline $1\{1977-1982\}$ & $\begin{array}{c}0.95^{* * *} \\
(0.36)\end{array}$ & $\begin{array}{c}0.19 \\
(0.22)\end{array}$ & $\begin{array}{l}-0.85 \\
(0.53)\end{array}$ & $\begin{array}{c}6.70^{* * * *} \\
(0.46)\end{array}$ & $\begin{array}{c}-1.04^{* *} \\
(0.40)\end{array}$ & $\begin{array}{c}-1.51^{* * *} \\
(0.43)\end{array}$ & $\begin{array}{c}-2.15^{* * *} \\
(0.46)\end{array}$ & $\begin{array}{c}-0.13 \\
(0.34)\end{array}$ \\
\hline $1\{1982-1987\}$ & $\begin{array}{c}4.50^{* * * *} \\
(0.37)\end{array}$ & $\begin{array}{c}3.87^{* * * *} \\
(0.21)\end{array}$ & $\begin{array}{c}4.00^{* * * *} \\
(0.42)\end{array}$ & $\begin{array}{c}5.77^{* * * *} \\
(0.45)\end{array}$ & $\begin{array}{c}0.13 \\
(0.40)\end{array}$ & $\begin{array}{c}1.25^{* * *} \\
(0.43)\end{array}$ & $\begin{array}{c}1.17^{* * *} \\
(0.44)\end{array}$ & $\begin{array}{c}1.36^{* * *} \\
(0.46)\end{array}$ \\
\hline $1\{1987-1992\}$ & $\begin{array}{c}2.39^{* * * *} \\
(0.29)\end{array}$ & $\begin{array}{c}1.73^{* * *} \\
(0.14)\end{array}$ & $\begin{array}{c}1.12^{* * *} \\
(0.26)\end{array}$ & $\begin{array}{c}3.75^{* * *} \\
(0.23)\end{array}$ & $\begin{array}{c}-0.61^{* * *} \\
(0.22)\end{array}$ & $\begin{array}{c}-0.77^{* * * *} \\
(0.24)\end{array}$ & $\begin{array}{c}-1.23^{* * * *} \\
(0.24)\end{array}$ & $\begin{array}{l}-0.05 \\
(0.28)\end{array}$ \\
\hline $1\{1992-2002\}$ & $\begin{array}{c}3.55^{* * *} \\
(0.44)\end{array}$ & $\begin{array}{c}2.71^{* * * *} \\
(0.15)\end{array}$ & $\begin{array}{c}1.43^{* * *} \\
(0.26)\end{array}$ & $\begin{array}{c}2.60^{* * *} \\
(0.26)\end{array}$ & $\begin{array}{c}-1.29^{* * * *} \\
(0.28)\end{array}$ & $\begin{array}{l}-0.18 \\
(0.27)\end{array}$ & $\begin{array}{l}-0.22 \\
(0.29)\end{array}$ & $\begin{array}{l}-0.11 \\
(0.24)\end{array}$ \\
\hline $1\{2002-2007\}$ & $\begin{array}{c}3.43^{* * * *} \\
(0.23)\end{array}$ & $\begin{array}{c}2.94^{* * * *} \\
(0.18)\end{array}$ & $\begin{array}{c}0.49 \\
(0.35)\end{array}$ & $\begin{array}{c}3.53^{* * * *} \\
(0.47)\end{array}$ & $\begin{array}{c}-2.46^{* * * *} \\
(0.33)\end{array}$ & $\begin{array}{c}-2.10^{* * * *} \\
(0.35)\end{array}$ & $\begin{array}{c}-2.39^{* * * * *} \\
(0.40)\end{array}$ & $\begin{array}{c}-1.55^{* * * *} \\
(0.33)\end{array}$ \\
\hline Exclude Computer Sector & No & Yes & Yes & Yes & Yes & Yes & Yes & Yes \\
\hline Number of Industries & 387 & 359 & 359 & 359 & 359 & 359 & 359 & 359 \\
\hline $\mathrm{N}$ & 1935 & 1795 & 1795 & 1795 & 1795 & 1795 & 1795 & 1795 \\
\hline
\end{tabular}

Notes: All specifications are based on a sample of 387 4-digit manufacturing industries observed over five periods. Each column reports results from regressing $100 \mathrm{x}$ annual log changes in the indicated variable on $100 \mathrm{x}$ annual changes in computer investments as a share of total investments, over the periods 1977-1982, 1982-1987, 1987-1992, 1992-2002, and 2002-2007. Columns (2)-(8) exclude a set of computer-related industries, based on the definition of the computer sector used in Bartik, Houseman, and Sturgeon (2013). In columns (7) and (8), "Prod" and "Non-Prod" refer to production workers and non-production workers, respectively. Industries are weighted by their average share of manufacturing employment over the period 1977-2007. Standard errors in parentheses are clustered on industry. ${ }^{*} \mathrm{p}<0.10,{ }^{* *} \mathrm{p}<0.05,{ }^{* * *} \mathrm{p}<0.01$. 